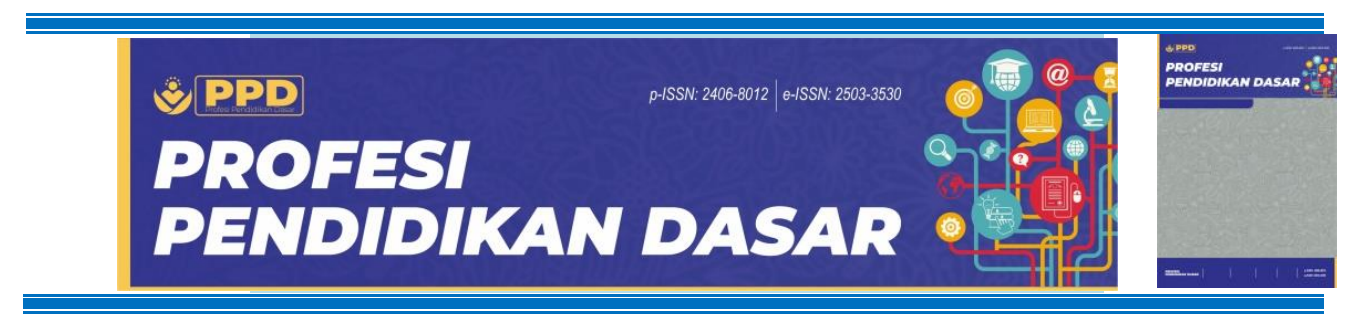

\title{
Development of E-Comic Teaching Materials for Social Studies Learning in Elementary Schools
}

Hana Dinah Fadilah

Universitas Negeri Jakarta, Jakarta, Indonesia

*Email: hanadinahf@gmail.com

\begin{tabular}{|c|c|}
\hline \multicolumn{2}{|c|}{$\begin{array}{l}\text { Submitted: 2021-07-17 } \\
\text { Accepted: 2021-12-16 } \\
\text { Published: 2021-12-23 }\end{array}$} \\
\hline Keywords: & Abstract \\
\hline $\begin{array}{l}\text { elementary } \\
\text { school; } \\
\text { e-comic; } \\
\text { social studies } \\
\text { learning; }\end{array}$ & $\begin{array}{l}\text { The purpose of this research was to develop mobile learning-based e-comic } \\
\text { social studies teaching materials to pique the interest of fifth-graders in } \\
\text { elementary school. The students in this study were from the fifth grade at } \\
\text { Riyadh El Jannah Islamic School. The ADDIE model was used to conduct } \\
\text { research development or research and development in this study. However, it } \\
\text { only reached the development stage due to circumstances that prevent it from } \\
\text { completing all of the stages. This research used a questionnaire for expert } \\
\text { evaluation as well as interviews with teachers and students. This study } \\
\text { employed descriptive quantitative and descriptive qualitative data analysis } \\
\text { techniques. The quantitative descriptive method is used to process expert data } \\
\text { and student response questionnaires, while the qualitative descriptive method } \\
\text { is used to describe corrective comments and validators' inputs. The feasibility } \\
\text { test for mobile learning-based e-comic teaching materials received an } \\
\text { average percentage of } 93.78 \text { percent, making it a worthy category. The final } \\
\text { scores for product trials on teacher and student responses were } 92 \text { percent } \\
\text { and } 94.57 \text { percent, respectively. Based on the findings of the data analysis, it } \\
\text { can be concluded that the developed mobile learning-based e-comic teaching } \\
\text { materials are suitable for classroom use.. }\end{array}$ \\
\hline
\end{tabular}

\section{INTRODUCTION}

\section{Background}

Education is one of the most fundamental processes in adjusting to one's surroundings in order to achieve a goal or achieve success. Education can be defined as educators' efforts to develop knowledge and skills for the benefit of humanity. Learning objectives, students, educators, curriculum, materials or subject matter, approaches, methods, media, learning resources, and evaluation are all components of education (Ratnasari, 2017). Social studies learning allows students to gain in-depth knowledge related to the environment, including those that cover the four competencies in the 2013 curriculum objectives (Saputri \&

(C) The Author(s). 2021

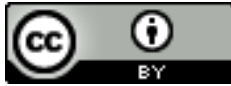

This work is licensed under a Creative Commons Attribution 4.0 International License 
Estiastuti, 2018). Social studies education is an adaptation of a series of social sciences and humanities that are combined into a single unit in a medium, as well as social studies learning, which is the implementation of education in schools (Hilmi, 2017). The purpose of social studies learning is to educate a community's life based on good moral and ethical values and can uphold the nation's cultural values and also aims to form students who have the knowledge, national insight, skills, social ethics, and high social character (Rosidah, 2017). The term social studies in elementary school are the name of a subject that combines a series of concepts from the social sciences, humanities, science, and various themes of life and social problems (Yuanta, 2019). Social studies in elementary schools aims to teach and guide students to become good citizens, have knowledge and perceptions, skills, and also social concerns that can be useful for students themselves, society, and the country (Rosmalina, 2019).

During the learning process, teaching materials become one of the components that can determine whether learning is exciting or not. The factors influencing whether or not the learning process is interesting are also influenced by the teaching materials used for learning (Rohmah, 2017). Teaching materials are media where teachers provide information or knowledge to students, and teaching materials are also learning materials that are systematically arranged for use by teachers and students in the learning process at school (Husada et al, 2020).

\section{Problem of Study}

The problem that often occurs in elementary school students, especially in social studies learning, is the use of learning media that are less attractive to students and do not always use media in the learning process (Sari, 2017). According to Adhaningrum (2020), the issues encountered during the implementation of social studies learning in the Indonesian thematic curriculum 2013 are ineffective learning materials used by students, resulting in an ineffective learning process.

Based on the aforementioned issues, several researchers concluded that comics teaching materials were appropriate for use in the elementary school social studies learning process. According to the findings of Prihanto \& Yunianta (2018)'s study, the Mathematics comic learning media can assist students in learning, and the Mathematics comic media has been declared valid, effective, and practical to use for learning Mathematics in elementary schools. According to Indaryati \& Jailani (2015)'s research, studying comics can boost students' motivation and achievement, and the findings show that comics are effective and practical for learning mathematics. Sari (2017) discovered that using comic books as learning materials in elementary schools is successful.

An e-comic based on mobile learning was developed in social studies learning in elementary schools to aid in the resolution of the problems described. It is possible to increase students' imagination and interest in learning in a lesson by reading comic books or books with pictures and storylines. When combined with a variety of teaching methods, comics can help students become more engaged in the learning process (Nugraheni, 2017).

\section{State of the Art}

Comics are collections of images arranged in sequence and using characters in the story to increase the imagination of the reader (Hardiyanti et al, 2019). The comic itself contains the text that can be found in the conversation bubble, which serves to clarify the story in it, and comics are also pictured books that are liked by children. The comic itself comes from the French "comique", which is an adjective that means funny or ridiculous. "Comique" itself comes from the Greek, namely comicos (Aeni \& Yusupa, 2018). According to Sudjana \& Rivai (Subroto et al, 2020), comics have several characteristics, including comics that consist of various serialized stories are entertaining, have other characteristics in them so 
that the power of comics can be well understood and can also focus attention. In the surrounding environment, readers can identify themselves with the feelings and behaviour of the characters because the stories in comics can be about themselves, and stories that are packaged into concise comics and attract the reader's attention are also usually equipped with action stories and the making is more alive because with the free use of primary colors in comics. In addition, learning media that uses comics as a medium of learning will make it easier for teachers when providing subject matter, and this can help educators understand or accept material (Subroto et al., 2020).

Comics can now be created digitally without the need for printing in today's world. Electronic comics are a type of technological media that aims to improve understanding of the concept of early childhood knowledge while also serving as a learning medium that appeals to children's interests (Syarah et al, 2018). Electronic comics are also known as digital comics, and technological advancements have an impact on comics in today's digital world (Ruiyat et al, 2019). The use of electronic comics teaching materials that combine pictures and text can help children understand some concepts while they are learning.

This study differs from previous research in that it created an E-Comic teaching material for social studies learning for fifth-grade elementary schools. And the E-Comic that will be developed is in the form of a strip. The developed E-Comic is in the form of a strip. A comic strip is a comic that has only a few panels of pictures but can express a complete and clear idea in terms of content. The E-Comic can be used as a media tool in fifth-grade social studies lessons in elementary schools. The author prefers E-Comic teaching materials because they have several advantages, including: increasing student interest in learning, making the material more appealing to students, assisting students in understanding abstract concepts, and providing storylines that cover the material Kanti et al, 2018). Students benefit from using this E-Comic teaching material because it does not require an internet connection, allowing them to learn independently without having to wait for instructions from the teacher. To draw students' attention to the content of this E-Comic, it will be packaged into an illustrated storyline.

\section{Gap Study \& Objective}

Comic books are typically packaged in a book, but with the advancement of technology in the modern era, comics are now also available in electronic form, referred to as mobile comics (Anesia et al, 2018). Social studies comics were created on a mobile platform, allowing users to take them with them wherever they go. Comics in the form of mobile apps can also help to reduce paper consumption (Hadi \& Dwijananti, 2015). Subroto et al (2020), conducted previous research on comics and concluded that comics are effective for use in learning because they contain many colors and images, making the material easier to understand. Styaningsih et al (2016), found that using digital comics teaching materials in Civics learning increased student interest in learning. Another study was conducted by (Muliani, 2020) who discovered that comic books could be used to support learning activities in elementary schools to improve student learning outcomes in social studies classes.

Based on the foregoing, the researcher conducted this study with the goal of developing an engaging, efficient, and effective e-comic teaching material for the fifth grade in elementary schools based on mobile learning in social studies subjects that can help increase student interest in social studies learning in the fifth grade. 


\section{METHOD}

The research design that will be carried out is Research and Development (R\&D) research to develop teaching materials in the form of Mobile Learning-based E-Comic using the ADDIE model. The ADDIE model emerged in the 1990s, which was developed by Reiser and Mollenda. The researcher uses the ADDIE development model because it has a procedure that refers to the Research and Development (R\&D) stage, which has simple stages so that effective products can be developed. The ADDIE model has 5 stages, namely Analyze, Design, Development, Implementation, and Evaluation. However, due to conditions that did not allow using the 5 stages of the ADDIE model, this research was not continued until Implementation and Evaluation. The following is an explanation of each ADDIE stage in making Mobile Learning-based E-Comic teaching materials.

\section{Analyze}

This analysis stage aims to obtain and collect information for the required needs. At this stage, the researcher will first analyze the material and also analyze the needs (needs analysis). The subjects in this study were fifth-grade elementary school students.

\section{Design}

In the design, the researcher designed and developed an E-Comic based on Mobile Learning Social Sciences on the material of the Indonesian Nation's Resistance Against Invaders in the fifth grade of elementary school based on the results of the analysis in the previous stage.

\section{Development}

The development stage is the step where E-Comic is made based on an existing design. Then the teaching materials are validated by experts, which will be continued at the revision stage. Experts who will validate these teaching materials are material experts, media experts and language experts. After the product has been made, it enters the product testing stage which will be carried out by teachers and students.

\section{Instruments and Data Processing}

The instruments that will be used for data collection in this study are interviews with teachers, students and expert test assessment questionnaires. The data analysis technique that will be used in this research is descriptive quantitative and also descriptive qualitative. The quantitative descriptive method is used to process expert data and student response questionnaires, while the qualitative descriptive method is used to describe corrective comments and validators' inputs.

Data for the study is collected using custom-made instruments that will be distributed to teachers, students, and experts. For data analysis, this study employs a Likert scale of 1 5. The formula for calculating the ideal percentage is as follows:

$$
\mathrm{P}=\frac{S}{N} \times 100 \%
$$

Source : (Arikunto, 2012)

$P=$ ideal percentage

$\mathrm{S}=$ Number of components of research results

$\mathrm{N}=$ Total maximum score

The questionnaire response to the use of e-comic contained 5 criteria according to the questions asked. Changes from the results of the assessment of media experts, linguists, material experts from letters to scores that have been determined in table 1 : 
Table 1. Likert Scale of Validity Sheet

\begin{tabular}{ll}
\hline Interval & Criteria \\
\hline 5 & Very Good \\
4 & Good \\
3 & Sufficient \\
2 & Poor \\
1 & Very Poor \\
\hline \multicolumn{2}{l}{ Source : (Ulfah, 2014) }
\end{tabular}

The purpose of using an expert questionnaire is to determine the feasibility of the underdevelopment product so that the questionnaire's feasibility value can be obtained for each aspect. The conversion of scores into a statement of assessment criteria is shown in Table 2:

\begin{tabular}{cc} 
Table 2. Interpretation of Media Eligibilit Score \\
\hline Percentage (\%) & Criteria \\
\hline $0-20$ & Very Weak \\
$20<-\leq 40$ & Weak \\
$40<-\leq 60$ & Sufficient \\
$60<-\leq 80$ & Worthy \\
$80<-\leq 100$ & Very Worthy \\
\hline
\end{tabular}

Source : (Anesia et al, 2018)

Based on the criteria showed in Table 2, the media is said to be feasible if the percentage is $>60 \%$ of all aspects.

\section{RESULT}

As a result of this development research, an E-Comic based on Mobile Learning has been created. Using the ADDIE development model, but only up to the development stage due to unforeseen circumstances. The stages that researchers have completed are detailed below:

\section{Analyze}

Researchers gather and analyze the needs for e-comic teaching materials in the analysis phase by analyzing core competencies and basic competencies, as well as the learning objectives of fifth-grade elementary school students in the 2013 Indonesian national curriculum, and determining the materials to be used in e-comic teaching materials.

Students must be able to identify the important factors that lead to Indonesian colonialism and the Indonesian people's efforts to maintain their sovereignty, according to the curriculum's basic competency 3.4. The goal of studying this basic competency is for students to be able to recognize the background of European arrival in Indonesia and to be able to explain the events surrounding the arrival of European expeditions in Indonesia. The researcher decided to create an e-comic teaching materials based on the material of 
European colonization in Indonesia based on the competency analysis. The author also conducted a needs analysis by observing and interviewing teachers and fifth-grade students at the Riyadh El Jannah Islamic School. According to the results of the interview, there is still a shortage of social studies teaching materials, as students struggle to comprehend the history of European colonization in Indonesia.

Design

Researchers worked on determining the comic's title and theme, collecting references, determining the material, compiling the comic's framework, designing the e-writing comic's format, and designing the e-display comic's or panel at this stage.

\section{Drafting the e-comic}

The research moves on to the stage of drafting the e-comic material after the researcher determines the content of the lesson. Microsoft Word is used to create scripts and e-comic materials. The source material has been adjusted to the Basic Competency that was determined during the analysis stage, as well as combining several resources and making adjustments to make it understandable for students.

This e-comic is divided into four parts, each explaining why Europeans colonized Indonesia, as well as explaining Portuguese, Spanish, and Dutch colonization. The material is organized into easy-to-follow stories with appealing illustrations to keep students interested in reading the e-comic.

\section{E-comic creation tools and applications}

Computers, laptops, and the Cintiq Pro 13 pen were used to create the e-comic. Clip Studio Paint Ex and Adobe Photoshop are the media editing applications used. Freepik, a image resources website, is used to find suitable imaging materials..

\section{Illustration design}

Interesting illustrations are required to draw students' attention to this e-comic and encourage them to read it. The author establishes two main characters, Mr. Girdan as a teacher and Kido as a student, based on the previous stage's draft. To make it more interesting, the surrounding background of this e-comic cover has been adjusted to the colonial theme.

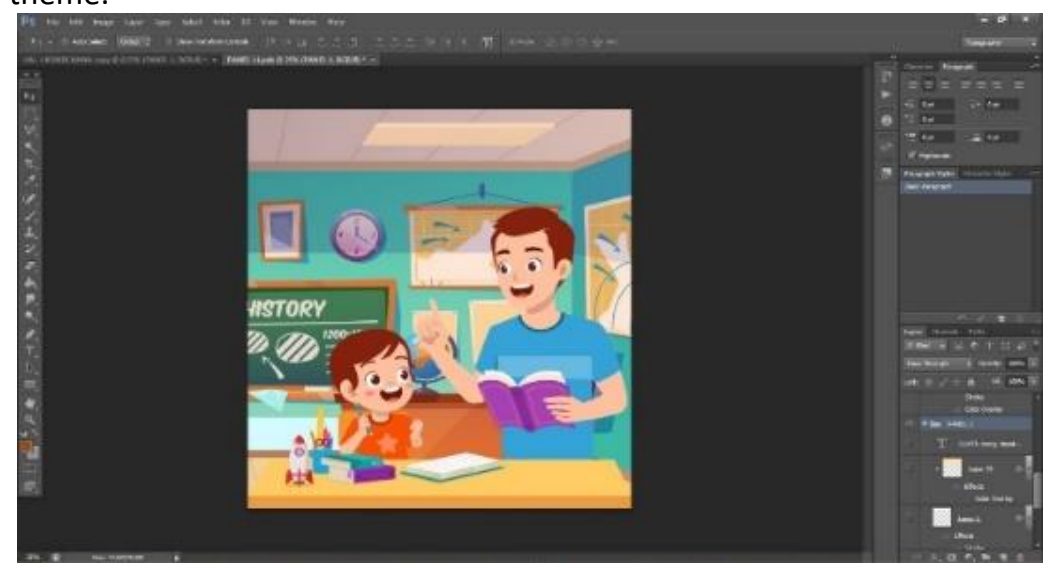

Figure 1. Illustration design display 


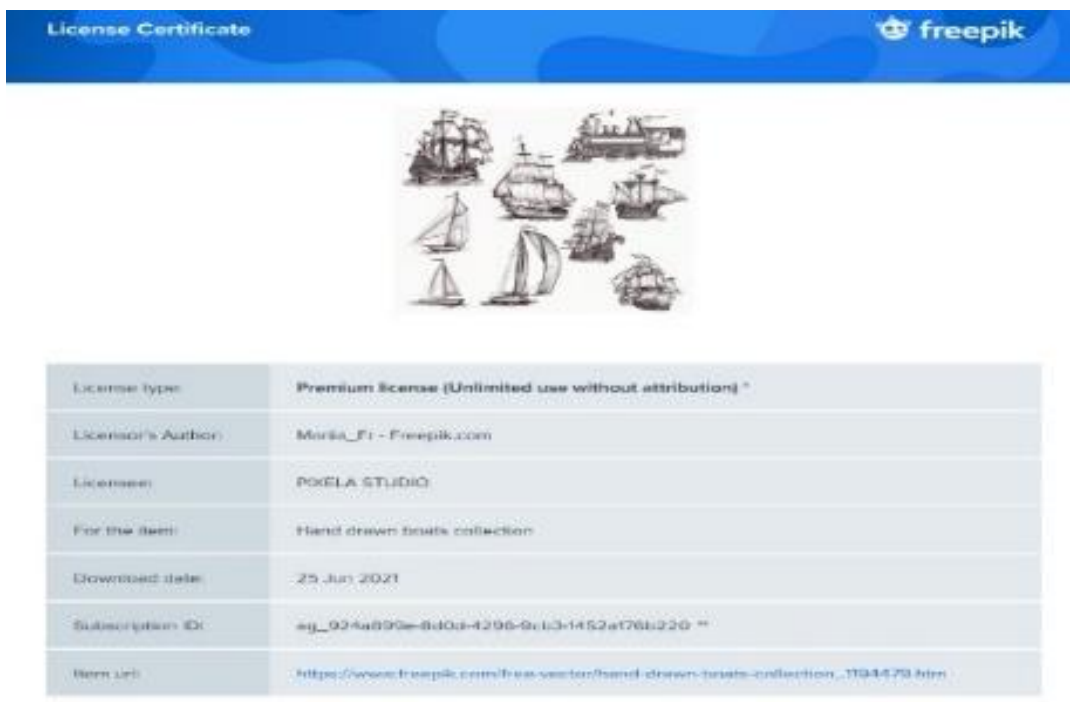

Figure 2. Illustration design display

\section{Development}

The e-comic is created based on a predetermined design during the development stage. Starting with the canvas, creating panels, locating the source of the illustration components, designing and combining the illustrations, and, if necessary, redrawing the illustrations. Following the completion of the teaching materials, they will be validated by material, media, and language experts.

\section{Canvas and panel making}

The canvas and panel must be created first. Adobe Photoshop CS6 is used for both of these projects. The canvas has a resolution of $4000 \times 5000$ pixels and a $300 \mathrm{dpi}$. The panels are sized to fit the size of the canvas..

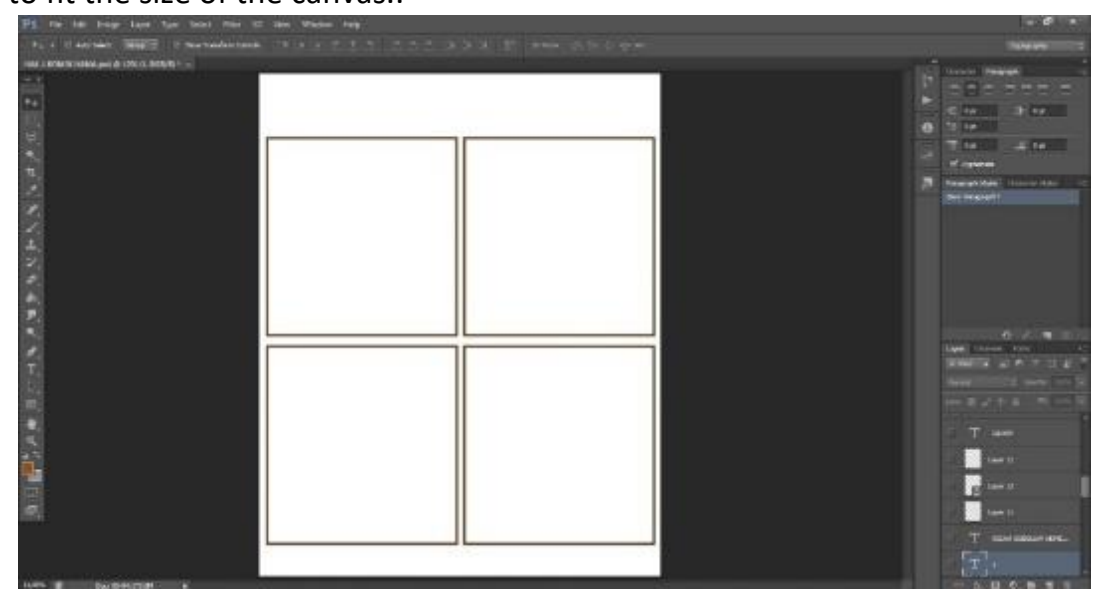

Figure 3. Canvas display and e-comic panels

\section{E-comic editing and illustration creation}

After the canvas and panels have been created, the e-development comic's team moves on to editing the rest of the e-components. book's Making panel boxes, word balloons, and adding extra designs like ancient effects, as well as making illustrations as needed, is the 
first step. The next step is to decide on the language for the e-story comic's and tailor it to the script. This procedure is repeated until the desired outcome has been achieved. Figure 4 shows the subsequent outcomes of the development.
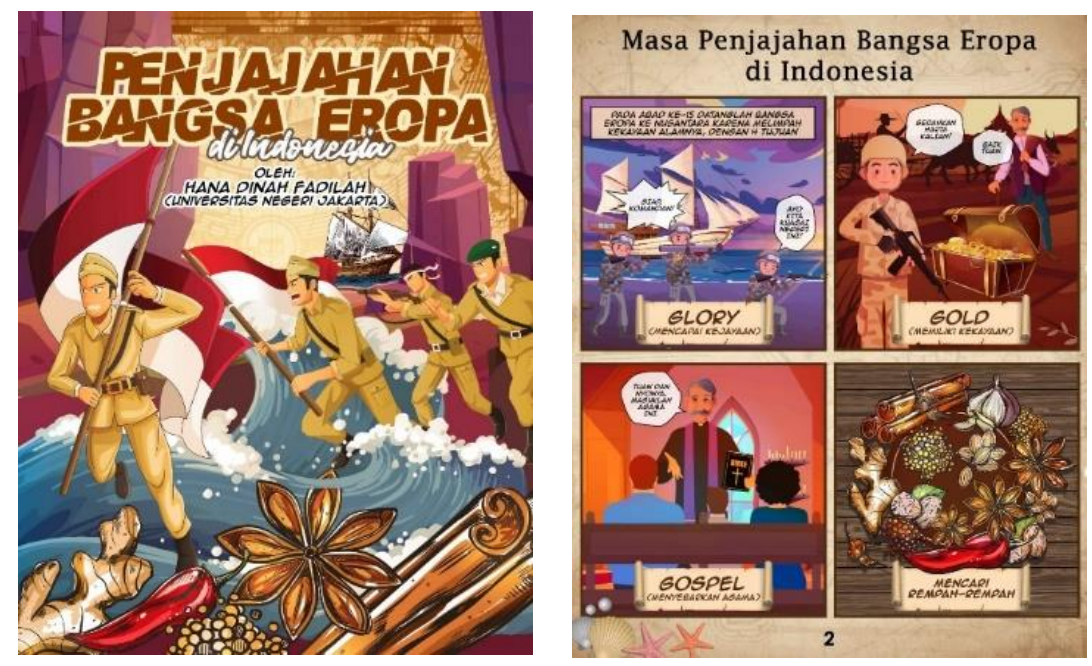

Figure 4. Cover and story display in e-comic

E-comic Validation Test

A validation test is a developed product assessment process that will be evaluated by the validator. A questionnaire with three aspects, namely the material aspect, the language aspect, and the media aspect, is used in the validation process. The goal of the validation is to see if the e-comic is suitable for research purposes.

Table 3. E-comic Validation Test

\begin{tabular}{lll}
\hline Expert Validator & Percentage (\%) & Criteria \\
\hline Material & $90,76 \%$ & Very Worthy \\
Language & $78,66 \%$ & Very Worthy \\
Media & $98,46 \%$ & Very Worthy \\
\hline Mean & $89,29 \%$ & \\
\hline
\end{tabular}

The product revision is carried out based on the validator's feedback and suggestions after it has been assessed by the validator in every aspect. The Figure 5 displays the e-comic after changes have been made. 

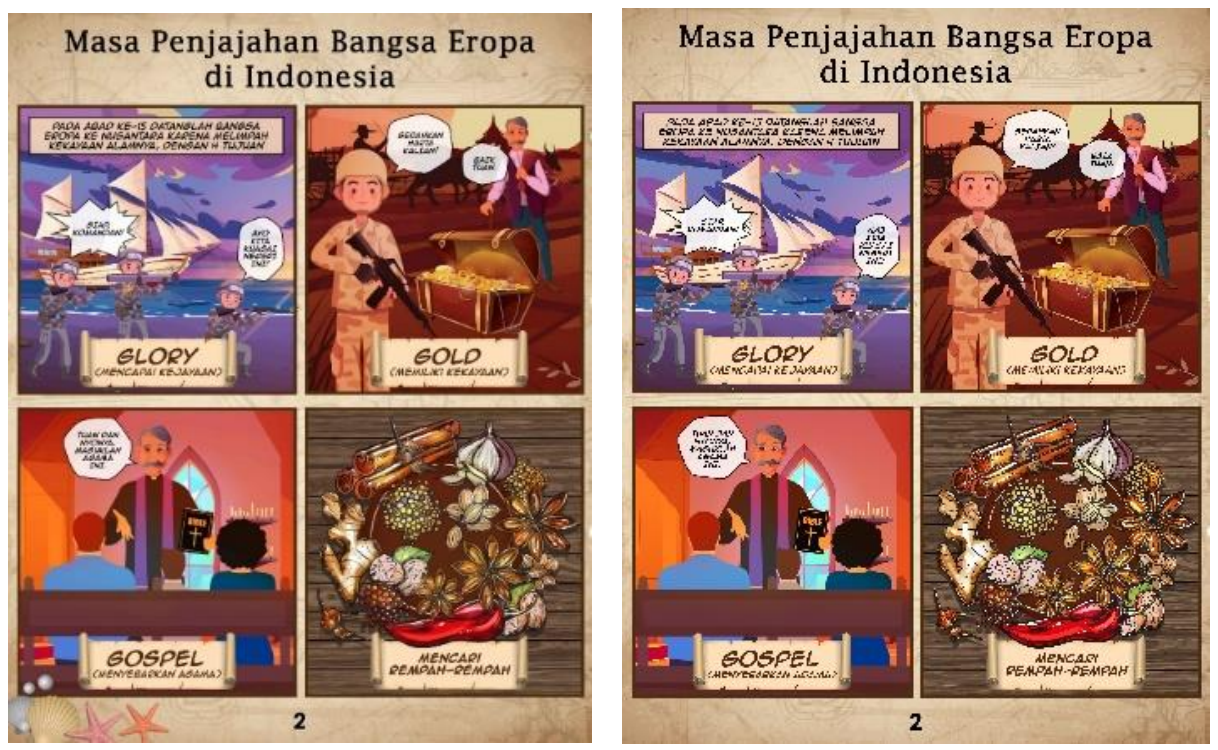

Figure 5. The display of e-comic after revision

\section{DISCUSSION}

This research creates an e-comic-style teaching plan for distance learning in social studies subjects for elementary school students. Using the ADDIE development model, but due to unforeseen circumstances, this study was not completed until the Implementation and Evaluation stage. Social Studies E-comic Teaching Materials Based on Mobile Learning Learning that has been developed is said to be excellent because it meets all of the requirements. The e-teaching comic's materials include information about the beginnings of European colonization in Indonesia. Teaching materials are accompanied by supporting illustrations that correspond to the material described, as well as stories that serve as material explanations, so that students can understand the material while reading. Illustrations are useful as supporting descriptions in clarifying the contents of an article because they provide a concrete and clear picture.

Furthermore, the e-comic teaching materials, based on the quality of the design of the teaching materials developed, contain detailed content and language that is easy to understand for students to understand the material. The attractiveness of illustrations varies and is interesting based on the characteristics that students possess. This media is thought to help students by attracting their attention and engaging them in self-directed learning.

The three validators' evaluations were obtained from the research that was conducted. On the basis of this evaluation, criticism and suggestions were obtained, which were used as a guide for improving the e-comic. By meeting assessment criteria such as the suitability of competence or learning objectives, the material presented is easy to understand, and the material's suitability with the image is very good, the above validation results obtained a percentage of 90.76 percent for the material aspect. The language aspect received 78.66 percent due to criteria such as the sentences used in the e-comic can represent the content of the message or information to be conveyed and the sentences used are communicative. Meeting the criteria for the accuracy of color selection on the e-comic character, the character design of the e-comic characters is attractive, and the presentation of the e-comic illustration has led to an understanding of the concept resulted in a 98.46 percent score for 
the media aspect. The overall average for these three elements is 89.29 percent. It can be concluded that this e-comic can be used effectively in social studies classes.

After expert product validation, product trials were given to teachers and students to see how they reacted to the e-comic based on the questionnaire that had been created. The teacher's response received a final score of 92 percent, while the average student response received a score of 94.57 percent. Based on the results of the survey, it can be concluded that e-comic teaching materials are ideal for use in social studies classes.

The findings are similar to those of Wicaksana et al (2019), who created an e-comic about the struggle for Indonesian independence, which received an average rating of 93.78 percent, indicating that it is suitable for classroom use and can increase students' interest in learning about the struggle of Indonesian independence preparations.

Another study conducted by Laksmi \& Suniasih (2021), on the development of e-comic in fifth-grade elementary school students was also found to be suitable for use in elementary school, with a percentage result of $90 \%$ on individual test subjects and a validator assessment average of 98 percent from content experts, learning experts, learning design experts, and learning media experts.

\section{CONCLUSION}

This study develops e-comic teaching materials for distance learning in social studies in elementary schools, focusing on European colonization of Indonesia. Several validators reviewed the e-comic for material, language, and media. The average percentage for teacher responses was 92 percent, and the average score for student responses was 94.57 percent, according to the validator's assessment. This e-comic teaching material can be concluded to be appropriate for learning.

\section{REFERENCES}

Adhaningrum, Sofia Agustin. 2020. "Pengembangan Bahan Ajar IPS Kontekstual Tema Wirausaha Di Kelas 6 Sekolah Dasar." Jurnal Penelitian Dan Pendidikan IPS 14(1):4454. doi: 10.21067/jppi.v14i1.4746.

Aeni, Wiwik Akhirul, and Ade Yusupa. 2018. "Model Media Pembelajaran E-Komik Untuk SMA." Jurnal Teknologi Pendidikan 6(1):1. doi: 10.31800/jtpk.v6n1.p1--12.

Anesia, Regita, B. .. Anggoro, and Indra Gunawan. 2018. "Pengembangan Media Komik Berbasis Android Pada Pokok Bahasan Gerak Lurus." Indonesian Journal of Science and Mathematics Education 1(1):53-57.

Arikuto, Suharsimi. 2012. Dasar - Dasar Evaluasi Pendidikan. Jakarta: Bumi Aksara.

Hadi, W, S., and P. Dwijananti. 2015. "Pengembangan Komik Fisika Berbasis Android Sebagai Suplemen Pokok Bahasan Radioaktivitas Untuk Sekolah Menengah Atas." UPEJ (Unnes Physics Education Journal) 4(2). doi: 10.15294/upej.v4i2.7431.

Hardiyanti, Dwi Astuti, Fina Fakhriyah, and Irfai Fathurohman. 2019. "PENGEMBANGAN MEDIA KOMIK STRIP BERBASIS KEUNGGULAN LOKAL PADA MATERI GAYA DAN CERITA FIKSI DI KELAS IV MUATAN BAHASA INDONESIA DAN ILMU PENGETAHUAN ALAM." Seminar Nasional Pagelaran Pendidikan Dasar Nasional (PPDN) 1(1):397-407.

Hilmi, Muhammad Zoher. 2017. "Implementasi Pendidikan IPS Dalam Pembelajaran IPS Di Sekolah." Jurnal Ilmiah Mandala Education 3(2):164-72.

Husada, Syahda Puspita, Taufina Taufina, and Ahmad Zikri. 2020. "Pengembangan Bahan Ajar Pembelajaran Tematik Dengan Menggunakan Metode Visual Storytelling Di Sekolah Dasar." Jurnal Basicedu 4(2):419-25. doi: 10.31004/basicedu.v4i2.373.

Indaryati, and Jailani. 2015. "Pengembangan Media Komik PembelajaranMatematika Meningkatkan Motivasi Dan Prestasi Belajar Siswa Kelas V." Prima Edukasia 3(1):8496. 
Kanti, Fitra Yurisma, Bambang Suyadi, and Wiwin Hartanto. 2018. “Pengembangan Media Pembelajaran Komik Digital Pada Kompetensi Dasar Sistem Pembayaran Dan Alat Pembayaran Untuk Siswa Kelas X Ips Di Man 1 Jember." JURNAL PENDIDIKAN EKONOMI: Jurnal IImiah IImu Pendidikan, IImu Ekonomi Dan IImu Sosial 12(1):135. doi: 10.19184/jpe.v12i1.7642.

Laksmi, Ni Luh Putu Ari, and Ni Wayan Suniasih. 2021. "Pengembangan Media Pembelajaran E-Comic Berbasis Problem Based Learning Materi Siklus Air Pada Muatan IPA." Jurnal Imiah Pendidikan Dan Pembelajaran 5(1):56. doi: 10.23887/jipp.v5i1.32911.

Muliani, Fitri. 2020. "PEMBANGAN MEDIA PEMBELAJARAN BERUPA BUKU KOMIK PADA MATERI SEJARAH DI SEKOLAH DASAR ( Studi Kasus: SD Negeri 148 Pekanbaru )." Jurnal Edukasi Dan Teknologi Pembelajaran 1(1):40-52.

Nugraheni, Nursiwi. 2017. "Penerapan Media Komik Pada Pembelajaran Matematika Di Sekolah Dasar." Refleksi Edukatika: Jurnal IImiah Kependidikan 7(2):111-17. doi: 10.24176/re.v7i2.1587.

Prihanto, D. A., and T. N. H. Yunianta. 2018. "Pengembangan Media Komik Matematikapada Materi Pecahan Untuk Siswa Kelas V Sekolah Dasar." MAJU: Jurnal IImiah ... 5(1):79_ 90.

Ratnasari, Ika Wanda. 2017. "Hubungan Minat Belajar Terhadap Prestasi Belajar Matematika." 5(2):289-93.

Rohmah, Dina Fitrohtur. 2017. "Pengembangan Buku Ajar IPS SD Berbasis Kontekstual." Jurnal Pendidikan: Teori, Penelitian, Dan Pengembangan 2(5):719-23.

Rosidah, Ani. 2017. "PENERAPAN MODEL PEMBELAJARAN KOOPERATIF SNOWBALL THROWING UNTUK MENINGKATKAN HASIL BELAJAR SISWA PADA PEMBELAJARAN IPS." Jurnal Cakrawala Pendas 3(2).

Rosmalina, Rosmalina. n.d. "Tinjauan Perkembangan Kurikulum IPS SD." Perkembangan Kurikulum Pendidikan IPS SD Rosmalina 2019:1-37.

Ruiyat, Suci Aprilyati, Yufiarti Yufiarti, and Karnadi Karnadi. 2019. "Peningkatan Keterampilan Berbicara Dengan Bercerita Menggunakan Komik Elektronik Tematik." Jurnal Obsesi: Jurnal Pendidikan Anak Usia Dini 3(2):518. doi: 10.31004/obsesi.v3i2.256.

Saputri, sari mei, and Arini Estiastuti. 2018. "Pengembangan Komik Berbasis Multimedia Powerpoint Dengan Model Inquiry Ips Kelas Iv." Joyful Learning Journal 7(3):29-38. doi: 10.15294/jlj.v7i3.24582.

Sari, Yunita. 2017. "Pengembangan Bahan Ajar Komik Ipa Dengan Penanaman Nilai Budai Pada Siswa Kelas Iv Sekolah Dasar." Jurnal Pendidikan Sekolah Dasar 3(2):129. doi: 10.30870/jpsd.v3i2.2134.

Styaningsih, Harum Aris, Winaro, and Muh Hendri Nuryadi. 2016. "PENGARUH PENGGUNAAN MEDIA KOMIK DIGITAL TERHADAP UPAYA PENEGAKAN MINAT BELAJAR PPKN SISWA PADA KOMPETENSI DASAR MENDESKRIPSIKAN KASUS PELANGGARAN DAN UPAYA PENEGAKAN HAM." Jurnal Profesi Pendidik 3(2):129-40.

Subroto, Erlanda Nathasia, Abd. Qohar, and Dwiyana. 2020. "Efektivitas Pemanfaatan Komik Sebagai Media Pembelajaran Matematika." Jurnal Pendidikan: Teori, Penelitian, Dan Pengembangan 5(2006):135-41.

Syarah, Erie Siti, Elindra Yetti, and Lara Fridani. 2018. "Pengembangan Media Komik Elektronik Untuk Meningkatkan Pemahaman Konservasi Anak Usia Dini." JPUD - Jurnal Pendidikan Usia Dini 12(2):231-40. doi: 10.21009/jpud.122.04.

Ulfah, Alifah. 2014. "Pengembangan Media Audio Visual Pada Kompetensi Penerapan Teknik Perlakuan Kimiawi Enzimatis Di SMKN 2 Indramayu."

Wicaksana, I. Putu Gde Caesar Renddy, Anak Agung Gede Agung, and I. Nyoman Jampel. 2019. “Pengembangan E-Komik Dengan Model Addie Untuk Meningkatkan Minat 
Belajar Tentang Perjuangan Persiapan Kemerdekaan Indonesia." Jurnal EDUTECH Universitas Pendidikan Ganesha 7(2):48-59.

Yuanta, Friendha. 2019. "Pengembangan Media Video Pembelajaran IImu Pengetahuan Sosial Pada Siswa Sekolah Dasar." Trapsila: Jurnal Pendidikan Dasar 1(2):91-100. 